\title{
A phylogenetic group of Escherichia coli associated with active left-sided Inflammatory Bowel Disease
}

\author{
Andreas M Petersen*1, Eva M Nielsen², Eva Litrup², Jørn Brynskov³, \\ Hengameh Mirsepasi ${ }^{2}$ and Karen A Krogfelt ${ }^{2}$
}

Address: ${ }^{1}$ Department of Gastroenterology, Hvidovre University Hospital, DK- 2650 Hvidovre, Denmark, ${ }^{2}$ Department of Bacteriology, Mycology and Parasitology, Statens Serum Institut, DK-2300 Copenhagen S, Denmark and ${ }^{3}$ Department of Gastroenterology, Herlev University Hospital, DK-2730 Herlev, Denmark

Email: Andreas M Petersen* - munk@dadlnet.dk; Eva M Nielsen - emn@ssi.dk; Eva Litrup - evl@ssi.dk; Jørn Brynskov - brynskov@dadlnet.dk; Hengameh Mirsepasi - pas@ssi.dk; Karen A Krogfelt - kak@ssi.dk

* Corresponding author

Published: 20 August 2009

BMC Microbiology 2009, 9:17| doi:|0.||86/|47|-2|80-9-|7|
Received: 2 March 2009

Accepted: 20 August 2009

This article is available from: http://www.biomedcentral.com/I47I-2180/9/17I

(C) 2009 Petersen et al; licensee BioMed Central Ltd.

This is an Open Access article distributed under the terms of the Creative Commons Attribution License (http://creativecommons.org/licenses/by/2.0), which permits unrestricted use, distribution, and reproduction in any medium, provided the original work is properly cited.

\begin{abstract}
Background: Escherichia coli have been found in increased numbers in tissues from patients with Inflammatory Bowel Disease (IBD) and adherent-invasive $E$. coli have been found in resected ileum from patients with Crohn's disesae. This study aimed to characterize possible differences in phylogenetic group (triplex PCR), extraintestinal pathogenic E. coli (ExPEC) genes and multilocus sequence type (MLST) between $E$. coli strains isolated from IBD patients with past or present involvement of the left side of the colon and from controls.

Results: Fecal samples were collected from 18 patients and from 10 healthy controls. Disease activity was evaluated by sigmoidoscopy. Interestingly, E. coli strains of the phylogenetic group B2 were cultured from $60 \%$ of patients with IBD compared to II\% of healthy controls $(p<0.05)$. Furthermore, when comparing the number of $E$. coli B2 strains with at least one positive ExPEC gene among different groups, $86 \%$ were found positive among active IBD patients, significantly more than $13 \%$ among inactive IBD patients $(\mathrm{p}<0.05)$, and II\% among healthy controls $(\mathrm{p}<0.05)$. The B2 phylogenetic group was found in a specific cluster based on MLST, but no further separation between $E$. coli strains associated with active compared to inactive IBD was achieved.

Conclusion: In conclusion, E. coli of the phylogenetic group B2 were isolated more frequently from IBD patients with past or present involvement of the left side of the colon compared to healthy controls, and B2 strains with ExPEC genes were found more frequently among IBD patients with active disease compared to patients with inactive disease.
\end{abstract}

\section{Background}

The pathogenic mechanisms of inflammatory bowel disease (IBD) have been researched intensely. In general, it is believed that both genetic and environmental factors are involved. When IBD was originally described, a close resemblance to infectious diseases of the gut was noticed.
Therefore, many different bacteria, viruses and other microorganisms have been suspected to cause IBD. It is now well established that luminal factors in the intestine are involved in the inflammatory process of Crohn's disease (CD) and ulcerative colitis (UC). For example, diversion of the continuity of the intestines results in healing of 
the resting gut, whereas the inflammation will return when continuity is reestablished [1]. Furthermore, several animal models have documented the participation of bacteria in the inflammatory process [2]. More importantly, the recent finding of a defect in the caspase recruitment domain family, member 15 (NOD2/CARD15), gene among CD patients, has reawakened the search for specific involved pathogens [3]. NOD2/CARD15 is believed to be involved in the innate immune system including the production of defensins; therefore, defects in this gene could indicate that the host is more susceptible to microorganisms [4]. It has also been shown that the number of viable internalized $S$. typhimurium in $\mathrm{Caco} 2$ cells was higher when the Caco 2 cells were transfected with a variant CARD15/NOD2 expression plasmid associated with Crohn's disease [5].

Escherichia coli are among the most interesting bacteria in the human gut. Certain E. coli clones with specific virulence factors are involved in extraintestinal infections the so called extraintestinal pathoghenic E. coli (ExPEC), and these bacteria often cause both urinary tract infections and septicemia. Furthermore, specific E. coli are involved in childhood diarrhea, (enteropathogenic E. coli), tourist diarrhea (enterotoxigenic E. coli), and recently, bloody diarrhea associated with hemolytic uremic syndrome (verotoxin-producing E. coli).

In the 1970's, it was found that hemolytic E. coli were linked to active $\mathrm{UC}$, although it was believed that the hemolytic E. coli were innocent bystanders, and their presence in the colon was assisted by the inflammation but did not cause it [6]. On the other hand, it has been shown that apathogenic E. coli prevents relapse of UC just as well as mesalazine [7]. Furthermore, E. coli has been linked to $\mathrm{CD}$, since an abundance of specific adherent-invasive $E$. coli was found in resected ileum from patients with $\mathrm{CD}$, compared to non inflamed ileum resected due to other causes $[8,9]$. Very recently, it was demonstrated by ribosomal intergenic spacer analysis that enterobacteriaceae are more abundant in tissue samples from patients with IBD compared to controls, and after culture, specific phylogenetic groups of $E$. coli were found to be more frequent among patients with UC and CD [10]. Moreover, it has been shown that $E$. coli are very predominant in inflamed mucosa of patients with UC, and that these strains based on 16 S rRNA PCR are "active" and overrepresented in comparison with the microbiota of healthy controls, who generally had a higher biodiversity of the active microbiota [11]. In addition, an exuberant inflammatory response to $E$. coli has been demonstrated among patients with UC [12].

The aim of our study was to characterize possible differences in phylogenetic group, serotype, ExPEC genes and virulence between $E$. coli isolated from patients with active IBD, patients with inactive disease and healthy controls, as well as to examine whether multilocus sequence typing (MLST) could further distinguish between these E. coli. MLST is considered the most stable and appropriate of currently available molecular typing techniques for long term epidemiology and for the identification of bacterial lineages that have an increased propensity to cause disease [13].

\section{Results}

Fecal samples were collected from 18 patients with IBD with present or past involvement of the left side of the colon and from 10 healthy controls. In both patients and controls, a sigmoidoscopy was performed. Ten patients were found to have a non-inflamed mucosa, whereas 8 had clear inflammation in the sigmoid colon. More detailed characteristics of patients are presented in Table 1. A total of 26 E. coli strains were isolated from study subjects. From 3 patients and 1 control, no E. coli could be isolated. From one patient with active IBD and one patient with inactive IBD two different $E$. coli strains from each patient were isolated based on MLST, serotyping and phylogenetic typing. From all controls and all other patients only one strain of $E$. coli from each subject was isolated.

E. coli strains were studied with respect to phylogenetic group, ExPEC genes, multilocus sequence type, serotype and virulence factors. Interestingly, among patients and controls with a positive E. coli culture, B2 strains were cultured most frequently from patients with IBD, 60\% (9 out of 15 ), compared to $11 \%$ ( 1 out of 9 ) from healthy controls $(\mathrm{p}<0.05)$. In addition, B2 E. coli strains were cultured most frequently from patients with active IBD, $86 \%$ (6 of 7), compared to $38 \%$ (3 of 8 ) among patients with inactive colitis, but this difference did not reach statistical significance $(\mathrm{p}=0.12)$. However, when comparing the number of B2 E. coli strains with at least one positive ExPEC gene among different groups (table 2), significantly more strains, $86 \%$ ( 6 of 7 ), were found positive among active IBD patients, compared to $13 \%$ (1 of 8 ) among inactive IBD patients $(\mathrm{p}<0.05)$ and $11 \%(1$ of 9$)$ among healthy controls $(\mathrm{p}<0.05)$. Among the $26 \mathrm{E}$. coli strains, representing 20 O-serogroups, 18 sequence types were identified using multilocus sequence typing (MLST) (figure 1). The B2 phylogenetic group associated with IBD was found in a specific cluster based on MLST, confirming a common ancestry of these IBD associated B2 E. coli, but no further separation was achieved between strains involved in active compared to inactive IBD. From most patients with active IBD, 71\%, E. coli were cultured with O-serotypes normally categorized as uropathogenic, compared to $25 \%(\mathrm{p}=0.13)$ in IBD in remission and $11 \%$ among healthy controls $(\mathrm{p}<0.05)$. Although hemolytic $E$. 
Table I: Characteristics of patients with active and inactive inflammatory bowel disease (IBD) and of controls.

\begin{tabular}{|c|c|c|c|c|c|}
\hline & Controls & Inactive UC & Active UC & Inactive CD & Active CD \\
\hline $\mathrm{N}$ & 10 & 5 & 6 & 5 & 2 \\
\hline id numbers & $\begin{array}{l}c^{1} 1, c 2, c 3, c 4, c 5, c 6, \\
c^{\prime} 2, c 14, c 16, c 17\end{array}$ & $\begin{array}{l}\text { p10, p23, p26, p27, } \\
\text { p32 }\end{array}$ & $\begin{array}{l}\text { p7, p8, p13, p19, p22, } \\
\text { p25 }\end{array}$ & $\begin{array}{l}\text { plI, p15, p18, p20, } \\
\text { p3l }\end{array}$ & p29, p30 \\
\hline$M / F$ & $6 / 4$ & $2 / 13$ & $5 / 1$ & $1 / 4$ & $2 / 0$ \\
\hline mean age & $27(2 \mid-33)$ & $40(37-54)$ & 42 (34-7I) & $48(34-65)$ & 48 \\
\hline $\begin{array}{l}\text { localization of disease, } \\
\text { (present when active, } \\
\text { previous when } \\
\text { inactive) }\end{array}$ & None & $\begin{array}{l}\text { Proctosigmoid colon } \\
\text { (p10, p23, } p 26), \\
\text { pancolitis }(p 32), \\
\text { rectum ( } p 27)\end{array}$ & $\begin{array}{l}\text { rectum }(p 8), \\
\text { proctosigmoid colon } \\
(p 7, p 19, p 22), \\
\text { pancolitis ( } p \mid 3, p 25)\end{array}$ & $\begin{array}{l}\text { descending colon } \\
\text { (pI5, pl8, p20), } \\
\text { proctosigmoid colon } \\
(p \mid 4, p 31)\end{array}$ & $\begin{array}{l}\text { colon with skip lesions } \\
\text { (p29), } \\
\text { proctosigmoid colon } \\
\text { (p30) }\end{array}$ \\
\hline Medication & None & $\begin{array}{l}\text { 5-ASA (p10, } 223, \\
\text { p26), } \\
\text { azathioprine (p27), } \\
\text { none (p32) }\end{array}$ & $\begin{array}{l}\text { 5-ASA (all), } \\
\text { Azathioprine ( } \mathrm{p} \mid 3, \\
\mathrm{p} \mid 9), \\
\text { prednisolone ( } \mathrm{p} \mid 3)\end{array}$ & $\begin{array}{l}\text { None }(p|5, p| 8, p 3 \mid), \\
5-A S A(p 20), \\
\text { prednisolone }(p \mid I)\end{array}$ & $\begin{array}{l}\text { 5-ASA (p29), none } \\
(p 30)\end{array}$ \\
\hline
\end{tabular}

UC; Ulcerative Colits, CD; Crohn's disease.

Controls have the prefix "c" and patients " $p$ ".

coli were isolated more frequently from patients with IBD $(47 \%)$ compared to healthy controls $(11 \%)$; this difference did not reach statistical significance $(\mathrm{p}=0.18)$.

No verotoxin producing strains were detected among the 26 E. coli isolates examined, and no other common virulence genes were significantly associated with disease activity based on hybridization assays (table 3 ).

\section{Discussion}

In our study based on fecal samples from patients with previous or present left-sided colitis and from controls, we found a strong correlation between isolation of E. coli of the phylogenetic group B2 and IBD; no correlation was found with other phylogenetic groups including group D. Further, we found a trend toward an association between the presence of B2 E. coli and active colitis. A recent study has demonstrated that the presence of specific E. coli (both groups B2 and D), in colonic biopsies, are associated with IBD, however patients were not stratified according to activity of the disease or to disease localization [10]. Our patients were well-defined regarding disease localization (left-sided colitis), which could explain the very specific association between B2 E. coli and IBD in our study. Controls (medical students) were younger than IBD patients, however, in broad terms the colonic microbiota is generally viewed as being a stable entity within an individual [14]. Moreover, previous studies of B2 E. coli did not show an increase in the probability of detecting a B2 E. coli with increasing age in the age groups participating in our study [15].
B2 strains are often found among ExPEC strains and when testing for 6 genes commonly associated with ExPEC [16], we found a statistically significant association between active IBD and B2 strains with at least one positive ExPEC gene, when comparing to both controls and to patients with inactive disease. The enhanced virulence potential of ExPEC strains is thought to be caused mainly by their multiple virulence factors such as adhesins, siderophores, toxin polysaccharide coatings; e.g., these virulence factors would help the bacteria to avoid host defenses, injure or invade host cells and tissues and stimulate a noxious inflammatory response [17]. It has been suggested that features, which commonly have been regarded as virulence factors in ExPEC isolates, are also factors promoting intestinal colonization [18-20]. This could explain why ExPEC strains are more prevalent in patients with UC, where the inflamed mucosa could prevent colonization with E. coli of a more commensal nature.

Whether IBD associated B2 E. coli can be differentiated from other B2 ExPEC strains is at present not known. In this regard it was interesting to find a possible association of the IBD associated B2 E. coli with afa, afimbrial adhesin, an adhesin which exist in different subtypes depending on the physiological site from which the afa positive E. coli were isolated [21]. Furthermore, the afimbrial adhesin has been demonstrated to cause functional lesions in the intestinal brush border, impairment of the epithelial barrier and proinflammatory responses in cultured human intestinal cells that express the structural and functional characteristics of human enterocytes [22]. 


\begin{tabular}{|c|c|c|c|c|c|c|c|c|c|c|c|c|c|c|c|}
\hline$\notin$ & $\stackrel{\infty}{\infty}, \stackrel{8}{5}$ & 善 & $\stackrel{0}{\underline{E}}$ & 离 &.$\underline{0}$ & 들 & 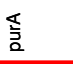 & $\begin{array}{l}\overleftarrow{\Phi} \\
\Phi\end{array}$ & Key & ST & Disease & O-type & K-type & H-type & Phylo group \\
\hline & & 13 & 40 & 34 & 13 & 23 & 28 & 30 & p13 & 91 & colitisA & 039 & K 4 & H4 & B2 \\
\hline & L & 13 & 40 & 13 & 13 & 23 & 25 & 66 & p10B & 357 & colitisl & Oru & $\mathrm{K} ?$ & $\mathrm{H} 4$ & $\mathrm{~B} 2$ \\
\hline & - & 14 & 14 & 10 & 14 & 17 & 7 & 10 & p22 & 14 & colitisA & O 18ac & K 5 & $\mathrm{H}-$ & $\mathrm{B} 2$ \\
\hline & ] & 37 & 38 & 19 & 37 & 17 & 11 & 26 & p30 & 95 & crohnA & 02 & K 1 & $\mathrm{H} 4$ & $\mathrm{~B} 2$ \\
\hline & $\pi$ & 37 & 38 & 19 & 37 & 17 & 11 & 26 & p31 & 95 & crohnl & 02 & K 1 & $\mathrm{H} 4$ & $\mathrm{~B} 2$ \\
\hline & & 36 & 24 & 9 & 13 & 17 & 11 & 25 & p7 & 73 & colitisA & 02 & K 2 & H 1 & B2 \\
\hline & & 36 & 24 & 9 & 13 & 17 & 11 & 25 & p25 & 73 & colitisA & 06 & K 5 & H 1 & B2 \\
\hline & & 36 & 24 & 9 & 13 & 17 & 11 & 25 & p32 & 73 & colitisl & 06 & K 43 & H 1 & B2 \\
\hline & & 36 & 24 & 9 & 13 & 17 & 11 & 25 & $\mathrm{p} 19 \mathrm{~A}$ & 73 & colitisA & 06 & K 2 & H 1 & B2 \\
\hline & 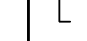 & 76 & 43 & 19 & 37 & 30 & 1 & 25 & $\mathrm{k} 1$ & 452 & control & O 81 & K 16 & $\mathrm{H}-$ & B2 \\
\hline & & 27 & 32 & 24 & 29 & 26 & 19 & 22 & $\mathrm{k} 16$ & 59 & control & 01 & K 1 & $\mathrm{H}-$ & D \\
\hline & & 6 & 8 & 4 & 1 & 9 & 48 & 7 & $\mathrm{k} 4$ & 210 & control & O 57,0155 & K 39 & $\mathrm{H} 19$ & B1 \\
\hline & & 6 & 4 & 22 & 18 & 9 & 26 & 7 & $\mathrm{k} 14$ & 99 & control & Oru & K 18 & $\mathrm{H} 19$ & B1 \\
\hline & L & 6 & 4 & 1 & 95 & 69 & 8 & 20 & $\mathrm{p} 10 \mathrm{~A}$ & 399 & colitisI & O125ac & $\mathrm{K}_{+}$ & $\mathrm{H} 10$ & A \\
\hline & & 9 & 6 & 15 & 131 & 24 & 7 & 7 & $\mathrm{k} 5$ & 711 & control & OX184 & $\mathrm{K}-$ & $\mathrm{H} 10$ & B1 \\
\hline & & 10 & 11 & 4 & 1 & 8 & 8 & 2 & p29 & 34 & crohnA & $\mathrm{O}+$ & K- & $\mathrm{H} 10$ & A \\
\hline & & 10 & 11 & 4 & 1 & 8 & 8 & 2 & $\mathrm{k} 17$ & 34 & control & 0101 & $\mathrm{~K}+$ & H56 & A \\
\hline & & 10 & 11 & 4 & 8 & 8 & 8 & 2 & $\mathrm{k} 2$ & 10 & control & 06 & K 39 & $\mathrm{H}-$ & A \\
\hline & & 10 & 11 & 4 & 8 & 8 & 8 & 2 & p26 & 10 & colitisI & O 9,0X186 & $\mathrm{K}_{+}$ & $\mathrm{H} 12$ & A \\
\hline & & 10 & 11 & 4 & 8 & 8 & 8 & 2 & p27 & 10 & colitisl & O 12 & K 1 & $\mathrm{H}-$ & A \\
\hline & & 21 & 35 & 27 & 6 & 5 & 5 & 4 & p15 & 69 & crohnl & O 17 & K 52 & $\mathrm{H} 18$ & $\mathrm{D}$ \\
\hline & & 21 & 35 & 27 & 6 & 5 & 5 & 4 & k3 & 69 & control & O 77 & K 96 & $\mathrm{H} 18$ & $\mathrm{D}$ \\
\hline & - & 126 & 160 & 131 & 6 & 5 & 5 & 99 & $\mathrm{k} 6$ & 714 & control & 0126 & $\mathrm{~K}-$ & $\mathrm{H} 20$ & $\mathrm{D}$ \\
\hline & $\Gamma$ & 34 & 36 & 28 & 25 & 28 & 16 & 4 & p11 & 5 & crohnl & O 23 & K 18 & $\mathrm{H} 15$ & $\mathrm{D}$ \\
\hline & 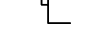 & 35 & 37 & 29 & 25 & 4 & 5 & 73 & p19B & 405 & colitisA & 02 & K 5 & H 4 & $\mathrm{D}$ \\
\hline & - & 51 & 48 & 132 & 139 & 34 & 42 & 100 & p23 & 715 & colitisI & 0156 & $\mathrm{~K}_{+}$ & $\mathrm{H}-$ & A \\
\hline
\end{tabular}

Figure I

Phylogenetic tree based on Multilocus Sequence Typing of Escherichia coli isolated from fecal samples from patients with active and inactive Inflammatory Bowel Disease, all with past or present involvement of the left side of the colon, and from controls. Also presented is serotype and phylogenetic groups A, BI, B2 or D. B2 strains are marked with a red box. Colitisl; inactive Ulcerative Colitis, colitisA; active Ulcerative Colitis, crohnl, inactive Crohn's disease, crohnA; active Crohn's disease. ST; sequence type.

MLST confirmed the common ancestry of the B2 E. coli, since they were all found in the same phylogenetic group, but unfortunately, no further information could be obtained regarding stratification of the B2 E. coli from active IBD patients compared to inactive IBD patients. Previously B2 E. coli strains have been described using MLST and subgroups have been identified [23], but our B2 strains were of sequence types typically found in different subgroups, making further information regarding these strains using MLST unlikely.

\section{Conclusion}

In conclusion, the clonal nature, based on MLST and phylogenetic group, of $E$. coli isolates from IBD patients with left-sided colitis contradicts an assumption that IBD through an impaired immune system simply allows an overrepresentation of $E$. coli at random. Some active participation by the microorganism is certainly indicated, either due to colonization advantages or as a part of IBD pathogenesis. Future studies of the effects of IBD associated E. coli in both cell assays and animal models will help to clarify the role of these bacteria in the inflammatory process.

\section{Methods \\ Subjects}

Permission for the study was obtained from the Regional Ethics Committee for Copenhagen County Hospitals (Permission no. KA03019) and all participants gave their informed written consent. Controls were recruited among medical students. All controls had a completely normal distal colon as visualized by video sigmoidoscopy at study entry. Patients with IBD were diagnosed according to standardised criteria [24,25], which included a fresh set of negative stool cultures for common pathogens including Clostridium difficile. All patients with CD had previous or 
Table 2: ExPEC genes in Escherichia coli isolated from fecal samples from patients with active and inactive IBD and from controls.

\begin{tabular}{|c|c|c|c|c|c|c|c|c|}
\hline Disease-Group & Reference number & Pap A 717 bp & afa 594 bp & Sfalfoc $410 \mathrm{bp}$ & lut 302 bp & kpsM I/ 272 bp & Pap C 205 bp & phylogenetic group \\
\hline control & cl & - & - & + & - & + & - & B2 \\
\hline control & c2 & - & - & + & - & - & - & $A$ \\
\hline control & c3 & - & - & - & - & - & - & $\mathrm{D}$ \\
\hline control & c4 & - & - & - & + & - & - & $\mathrm{BI}$ \\
\hline control & c5 & - & - & - & - & - & - & $\mathrm{BI}$ \\
\hline control & $c 6$ & - & - & - & - & - & - & $\mathrm{D}$ \\
\hline control & $\mathrm{cl} 4$ & - & - & - & - & - & - & $\mathrm{BI}$ \\
\hline control & cl6 & + & - & - & - & + & - & $\mathrm{D}$ \\
\hline control & $\mathrm{cl} 7$ & - & - & - & - & - & - & A \\
\hline \multirow[t]{2}{*}{ IBDI } & pIOA & - & - & - & - & - & - & $A$ \\
\hline & pIOB & - & - & - & - & - & - & B2 \\
\hline IBDI & pll & + & - & - & - & + & - & $D$ \\
\hline IBDI & pl5 & - & + & - & + & + & + & $D$ \\
\hline IBDI & p23 & - & - & - & - & - & - & $A$ \\
\hline IBDI & p26 & - & - & - & - & - & - & $A$ \\
\hline IBDI & p27 & - & + & - & - & + & - & $A$ \\
\hline IBDI & p3I & - & - & - & - & - & - & B2 \\
\hline IBDI & p32 & - & - & + & + & - & - & B2 \\
\hline IBDA & p7 & + & + & + & + & - & + & B2 \\
\hline IBDA & pl3 & - & - & - & - & + & - & B2 \\
\hline \multirow[t]{2}{*}{ IBDA } & pI9A & - & + & + & + & - & + & B2 \\
\hline & $\mathrm{p} / 9 \mathrm{~B}$ & - & + & - & - & + & - & $D$ \\
\hline IBDA & p22 & + & - & + & + & + & + & B2 \\
\hline IBDA & p25 & + & - & + & + & + & + & B2 \\
\hline IBDA & p29 & - & - & - & - & - & - & A \\
\hline IBDA & p30 & - & - & - & + & - & + & B2 \\
\hline
\end{tabular}

B2 strains with at least one positive ExPEC gene in bold.

present involvement of the left side of the colon. The basic clinical features of the study groups are presented in Table 1

\section{Samples and selection of $\mathrm{E}$. coli isolates}

Fecal samples from patients and controls were used in this study. Fecal samples were collected by patients and controls and submitted for culture at the Department of Bacteriology, Mycology and Parasitology, Statens Serum Institut, Copenhagen, Denmark, and E. coli colonies were chosen for further characterization by a lab technician without knowledge of the clinical data of the participating patients and controls.

\section{Microbiological methods}

Fecal cultures were performed by suspending $10 \mu \mathrm{l}$ or an amount equivalent to $10 \mu \mathrm{l}$ feces into $2 \mathrm{ml}$ of phosphatebuffered saline ( $\mathrm{pH}$ 7.38). The suspension was mixed, and $10 \mu \mathrm{l}$ was plated on SSI enteric medium [26] and incubated at $37^{\circ} \mathrm{C}$ overnight. The plates were examined for the colony characteristics, size, and colour of the cultured organisms. Colonies with characteristic features for $E$. coli were chosen for colony blot hybridization, serotyping and MLST. The strains were confirmed as being E. coli by using the Minibact E kit (Statens Serum Institut, Copenhagen, Denmark) [27]

\section{Serotyping}

The isolates were serotyped according to standard methods [28] using the full set of antisera (Statens Serum Institut, Hillerød, Denmark).

\section{DNA hybridization}

Virulence genes of common E. coli pathotypes were detected by DNA probe-hybridisation assays: verocytotoxin genes $(v t x 1, v t x 2)$ intimin (eae), enterohemolysin $(e h x A)$, bundle-forming pili ( $b f p A)$, EAST1 (astA), marker for enteroaggregative E. coli (aatA/CVD432) and marker for diffuse adherence (SLM862) as described previously $[29,30]$.

\section{MLST}

MLST was performed according to the scheme described at the E. coli MLST website maintained at the Max-Planck Institut für Infektionsbiologie http://web.mpiib-ber lin.mpg.de. The seven housekeeping genes were shown to be unlinked on an E. coli K-12 genome map. Product lengths varied from 583 to 932 bp. DNA was isolated 
Table 3: Serotype and phenotype of Escherichia coli isolated from fecal samples from patients with active and inactive IBD and from controls.

\begin{tabular}{|c|c|c|c|c|c|c|}
\hline Disease group & Reference number & Virulence Genes & O TYPE & K TYPE & H TYPE & Hemolysin \\
\hline Control & $\mathrm{cl}$ & - & O8। & $\mathrm{K} 16$ & $\mathrm{H}-$ & - \\
\hline Control & c2 & ast $A$ & 06 & K39 & $\mathrm{H}-$ & - \\
\hline Control & c3 & - & O77 & K96 & $\mathrm{HI} 8$ & - \\
\hline Control & c4 & - & O57, O155 & K39 & $\mathrm{HIO}$ & - \\
\hline Control & $c 5$ & - & OX184 & K- & $\mathrm{HIO}$ & - \\
\hline Control & c6 & - & 0126 & K- & $\mathrm{H} 2 \mathrm{O}$ & - \\
\hline Control & $\mathrm{cl} 2$ & ND & & & & \\
\hline Control & $\mathrm{cl} 4$ & - & Oru & $\mathrm{K} 18$ & $\mathrm{HIO}$ & - \\
\hline Control & $\mathrm{cl} 6$ & - & OI & $\mathrm{KI}$ & $\mathrm{H}-$ & Ent \\
\hline Control & $\mathrm{cl} 7$ & ast $A$ & OIOI & $\mathrm{K}+$ & $\mathrm{H} 56$ & - \\
\hline \multirow[t]{2}{*}{ IBD Inactive } & pIOA & - & OI25ac & $\mathrm{K}+$ & $\mathrm{HIO}$ & - \\
\hline & pIOB & - & Oru & $\mathrm{K}$ ? & $\mathrm{H} 4$ & - \\
\hline IBD Inactive & pll & - & $\mathrm{O} 23$ & $\mathrm{~K} 18$ & $\mathrm{HIS}$ & Ent. \\
\hline IBD Inactive & pl5 & ast $A$ & OI7 & K52 & $\mathrm{HI} 8$ & - \\
\hline IBD Inactive & pl8 & ND & & & & \\
\hline IBD Inactive & p20 & ND & & & & \\
\hline IBD Inactive & p23 & - & 0156 & $\mathrm{~K}+$ & $\mathrm{H}-$ & - \\
\hline IBD Inactive & p26 & - & $09,0 \times 186$ & $\mathrm{~K}+$ & $\mathrm{H} 12$ & Ent. \\
\hline IBD Inactive & $\mathrm{p} 27$ & - & 012 & $\mathrm{KI}$ & $\mathrm{H}-$ & Ent. \\
\hline IBD inactive & p3I & - & 02 & $\mathrm{KI}$ & $\mathrm{H} 4$ & - \\
\hline IBD Inactive & p32 & & 06 & K43 & $\mathrm{HI}$ & - \\
\hline IBD Active & p7 & ast $A$ & 02 & $\mathrm{~K} 2$ & $\mathrm{HI}$ & Ent \\
\hline IBD Active & $\mathrm{p} 8$ & ND & & & & \\
\hline IBD Active & $\mathrm{p} / 3$ & - & O39 & K4 & $\mathrm{H} 4$ & - \\
\hline \multirow[t]{2}{*}{ IBD Active } & pl9A & - & 06 & $\mathrm{~K} 2$ & $\mathrm{HI}$ & Alpha \\
\hline & pl9B & SLM862 & 02 & $\mathrm{~K} 5$ & $\mathrm{H} 4$ & - \\
\hline IBD Active & p22 & - & $018 \mathrm{ac}$ & K5 & $\mathrm{H}-$ & Alpha \\
\hline IBD Active & p25 & ast $A$ & 06 & $\mathrm{~K} 5$ & $\mathrm{HI}$ & Ent. \\
\hline IBD Active & p29 & aat $A$ & O+ & $\mathrm{K}-$ & $\mathrm{HIO}$ & - \\
\hline IBD Active & p30 & - & 02 & $\mathrm{KI}$ & $\mathrm{H} 4$ & - \\
\hline
\end{tabular}

Uropathogenic E. coli associated O-type in bold.

from the colonies using the ChargeSwitch ${ }^{\circledast}$ gDNA Mini Bacteria Kit (Invitrogen, Carlsbad, CA, USA), and stored at $-20^{\circ} \mathrm{C}$ until required for PCR amplification.

\section{Sequencing}

PCR reactions were performed on the purified DNA using PuReTaq Ready-To-Go ${ }^{\mathrm{TM}}$ PCR beads (Amersham Biosciences UK Limited, Buckinghamshire, England) by adding $1 \mu \mathrm{l}$ of extracted DNA ( $10 \mathrm{ng}$ DNA), $1 \mu \mathrm{l}$ of each

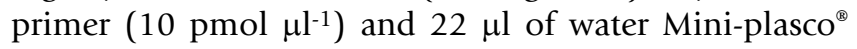
(Braun Melsungen AG, Melsungen, Germany). Primer sequences and cycling conditions were employed as described on the MLST website. PCR was performed on a GeneAmp ${ }^{\oplus}$ PCR System 9700 (Applied Biosystems, Foster City, CA, USA). PCR products were purified with the ChargeSwitch $^{\circledast}$ PCR Clean-Up Kit (Invitrogen) and sequenced by MWG Biotech (Ebersberg, Germany).

\section{Sequence analysis}

Raw sequences were reviewed by visual inspection in BioNumerics version 4.601 (Applied Maths, Sint-Mar-
tens-Latem, Beligium). DNA sequences were aligned and trimmed. Obtained sequences were aligned against known alleles in the database at the website, and allele numbers and sequence types were assigned. In the case of unknown alleles and/or sequence types, the new alleles and sequence types were submitted to the database. The phylogenetic tree is an UPGMA tree calculated in BioNumerics on the basis of the concatenated sequences.

\section{Phylogenetic group}

Phylogenetic groups (A, B1, B2 and D) were determined by a simple PCR procedure based on genes chuA, YjaA and an anonymous DNA fragment, using primers and conditions exactly as described by Clermont et al [31].

\section{ExPEC genes}

The presence of six ExPEC genes, papA ( $\mathrm{P}$ fimbriae), papC (pilus assembly), afa (afimbrial adhesion), sfa/foc (Sfimbriae/F1Ccfimbriae), iut (aerobactin system) and $k p s M$ (kapsular synthesis) was detected by a PCR method, using 
primers and conditions exactly as described by Johnson et al [16].

\section{Statistics}

The number of hemolysin positive E. coli, E. coli of serotypes typical for ExPEC, E. coli, with at least one positive ExPEC gene and B2 E. coli in different clinical groups were assessed with the Fisher Exact test (2-tailed). P $<0.05$ was considered significant.

\section{Authors' contributions}

AMP, JB, KAK participated in the design of the study. AMP and JB contacted patients and controls and performed the sigmoidoscopies, KAK was responsible for isolation of $E$. coli and microbiological tests. AMP and KAK drafted the manuscript and performed the statistical analysis. EMN, EVL and HMI performed the molecular genetic studies and serotyping. All authors read and approved the final manuscript.

\section{Acknowledgements}

We thank Berit Jensen and Susanne Jespersen for their excellent technical help and student Henrik Petersen, who performed parts of the MLST.

\section{References}

I. Janowitz HD, Croen EC, Sachar DB: The role of the fecal stream in Crohn's disease: an historical and analytic review. Inflamm Bowel Dis 1998, 4(1):29-39.

2. Madsen KL: Inflammatory bowel disease: lessons from the IL10 gene-deficient mouse. Clin Invest Med 200I, 24(5):250-7.

3. Hugot JP, Chamaillard M, Zouali H, Lesage S, Cezard JP, Belaiche J, Almer S, Tysk C, O'Morain CA, Gassull M, Binder V, Finkel Y, Cortot A, Modigliani R, Laurent-Puig P, Gower-Rousseau C, Macry J, Colombel JF, Sahbatou M, Thomas G: Association of NOD2 leucine-rich repeat variants with susceptibility to Crohn's disease. Nature 200I, 4 I I (6837):599-603.

4. Fellermann K, Wehkamp J, Herrlinger KR, Stange EF: Crohn's disease: a defensin deficiency syndrome? Eur J Gastroenterol Hepatol 2003, I 5(6):627-34

5. Hisamatsu T, Suzuki M, Reinecker HC, Nadeau WJ, McCormick BA, Podolsky DK: CARDI5/NOD2 functions as an antibacterial factor in human intestinal epithelial cells. Gastroenterology 2003, I 24(4):993-1000.

6. Cooke EM, Ewins SP, Hywel-Jones J, Lennard-Jones JE: Properties of strains of Escherichia coli carried in different phases of ulcerative colitis. Gut 1974, I5(2):143-6.

7. Kruis W, Schutz E, Fric P, Fixa B, Judmaier G, Stolte M: Double-blind comparison of an oral Escherichia coli preparation and mesalazine in maintaining remission of ulcerative colitis. Aliment Pharmacol Ther 1997, I I(5):853-8.

8. Darfeuille-Michaud A, Neut C, Barnich N, Lederman E, Di Martino P, Desreumaux P, Gambiez L, Joly B, Cortot A, Colombel JF: Presence of adherent Escherichia coli strains in ileal mucosa of patients with Crohn's disease. Gastroenterology 1998, I I 5(6): | 405-13.

9. Darfeuille-Michaud A, Boudeau J, Bulois P, Neut C, Glasser AL, Barnich N, Bringer MA, Swidsinski A, Beaugerie L, Colombel JF: High prevalence of adherent-invasive Escherichia coli associated with ileal mucosa in Crohn's disease. Gastroenterology 2004, I 27(2):4|2-2|.

10. Kotlowski R, Bernstein CN, Sepehri S, Krause DO: High prevalende of Escherichia coli belonging to the B2+D phylogentic group in inflammatory bowel disease. Gut 2007, 56:669-75.

II. Sokol H, Lepage P, Seksik P, Doré J, Marteau P: Temperature gradient gel electrophoresis of Fecal I6S rRNA reveals active Escherichia coli in the Microbiota of patients with ulcerative colitis. J Clin Microbiol 2006, 44(9):3 I72-7.
12. Marks DJ, Rahman FZ, Novelli M, Yu RC, McCarney S, Bloom S, Segal $A W$ : An exuberant inflammatory response to $E$. coli: Implications for the pathogenesis of ulcerative colitis and pyoderma gangrenosum. Gut 2006, 55(I I): I662-3.

13. Maiden MCJ, Bygraves JA, Feil E, Morelli G, Russell JE, Urwin R, Zhang Q, Zhou J, Zurth K, Caugant DA, Feavers IM, Achtman M, Spratt BG: Multilocus sequence typing: A portable approach to the identification of clones within populations of pathogenic microorganisms. PNAS 1998, 95:3140-5.

14. Bornside GH: Stability of human fecal flora. Am J Clin Nutr 1978, 3 I (Suppl):SI4I-SI44.

15. Gordon DM, Stern SE, Collignon PJ: Influence of the age and sex of human hosts on the distribution of Escherichia coli ECOR groups and virulence traits. Microbiology 2005, I 5 I: I5-23.

16. Johnson JR, Delavari P, Kuskowski M, Stell AL: Phylogenetic distribution of extraintestinal virulence-associated traits in Escherichia coli . J Infect Dis 200I, I 83:78-88.

17. Johnson JR: Microbial virulence determinants and the pathogenesis of urinary tract infection. Infect Dis Clin North AM 2003, I7(2):26I-78.

18. Nowrouzian F, Adlerberth I, Wold AE: $\mathbf{P}$ fimbriae, capsule and aerobactin characterize colonic resident Escherichia coli. Epidemiol Infect 2001, I 26(I): I I-8.

19. Nowrouzian F, Hesselmar B, Saalman R, Strannegard IL, Aberg N, Wold $\mathrm{AE}$, Adlerberth I: Escherichia coli in infants' intestinal microflora: colonization rate, strain turnover, and virulence gene carriage. Pediatr Res 2003, 54(I):8-I4.

20. Wold AE, Caugant DA, Lidin-Janson G, de Man P, Svanborg C: Resident colonic Escherichia coli strains frequently display uropathogenic characteristics. J Infect Dis 1992, I 65(I):46-52.

21. Le Bouguénec C, Lalioui L, du Merle L, Jouve M, Courcoux P, Bouzari S, Selvarangan R, Nowicki BJ, Germani Y, Andremont A, Gounon P, Garcia MI: Characterization of AfaE adhesins produced by extraintestinal and intestinal human Escherichia coli isolates: PCR assays for detection of Afa adhesins that do or do not recognize Dr blood group antigens. J Clin Microbiol 2001, 39(5): | 738-45.

22. Servin AL: Pathogenesis of Afa/Dr Diffusely Adhering Escherichia coli. Clinical Microbiol reviews 2005, I 8:264-92.

23. Le Gall T, Clermont O, Gouriou S, Picard B, Nassif X, Denamur E, Tenaillon $O$ : Extraintestinal virulence is a coincidental byproduct of commensalism in B2 phylogenetic group Escherichia coli strains. Mol Biol Evol 2007, 24(I I):2373-84.

24. Munkholm P, Langholz E, Nielsen OH, Kreiner S, Binder V: Incidence and prevalence of Crohn's disease in the county of Copenhagen, 1962-87: a sixfold increase in incidence. Scand J Gastroenterol 1992, 27:609-14.

25. Langholz E, Munkholm P, Davidsen M, Binder V: Course of ulcerative colitis: analysis of changes in disease activity over years. Gastroenterology 1994, 107:3-II.

26. Blom M, Meyer A, Gerner-Smidt P, Gaarslev K, Espersen F: Evaluation of Statens Serum Institut enteric medium for detection of enteric pathogens. Clin Microbiol 1999, 37:23 I 2-6.

27. Kjaeldgaard P, Nissen B, Lange N, Laursen H: Evaluation of Minibact, a new system for rapid identification of Enterobacteriaceae: comparison of Minibact, Micro-ID, and API 20E with a conventional method as reference. Acta Pathol Microbiol Immunol Scand 1986, 94:57-6I.

28. Ørskov F, Ørskov I: Serotyping of Escherichia coli . Methods Microbiol 1984, I4:43-II2.

29. Olesen B, Neimann J, Böttiger B, Ethelberg S, Schiellerup P, Jensen C, Helms M, Scheutz F, Olsen KE, Krogfelt K, Petersen E, Mølbak K, Gerner-Smidt P: Etiology of diarrhea in young children in Denmark: a case-control study. J Clin Microbiol 2005, 43(8):3636-4I.

30. Jensen C, Ethelberg S, Olesen B, Schiellerup P, Olsen KE, Scheutz F, Nielsen EM, Neimann J, Høgh B, Gerner-Smidt P, Mølbak K, Krogfelt $K A$ : Attaching and effacing Escherichia coli isolates from Danish children: clinical significance and microbiological characteristics. Clin Microbiol Infect 2007, I3(9):863-72.

31. Clermont $O$, Bonacorsi S, Bingen E: Rapid and simple determination of the Escherichia coli phylogenetic group. Appl Environ Microbiol 2000, 66:4555-8. 